\title{
OPTIMIZATION OF ANTIDOTISM IN CASES OF SKIN INJURIES CAUSED BY BLISTER AGENTS. EXPERIMENTAL STUDY
}

\author{
MIHAI-SILVIU TUDOSIE ${ }^{1}$, SIMONA BICHERU ${ }^{2}$, RUXANDRA AVRAM ${ }^{3}$, OANA AVRAM ${ }^{1,3}$, \\ CAMELIA ANDREEA VĂRZARU ${ }^{2}$, CRISTINA ANCA SECARĂ ${ }^{2}$, DRAGOȘ ȘERBAN ${ }^{1,4 *}$, \\ GABRIEL CĂTĂLIN SMARANDACHE ${ }^{1,4}$, CIPRIAN TĂNĂSESCU ${ }^{5}$, DRAGOȘ MARIAN \\ POPESCU $^{6}$, CORNELIU TUDOR $^{4}$, ANA MARIA DASCĂLU ${ }^{1}$, CRISTINEL DUMITRU BADIU $^{1,7}$ \\ 1 "Carol Davila" University of Medicine and Pharmacy Bucharest, Romania \\ 2 “Cantacuzino” National Medical-Military Research-Development Institute Bucharest, Romania \\ ${ }^{3}$ Emergency Clinic Hospital Bucharest, Romania \\ ${ }^{4} I V^{\text {th }}$ Department of General Surgery, Emergency University Hospital Bucharest, Romania \\ 5 "Lucian Blaga" University of Medicine and Pharmacy Sibiu, Romania \\ ${ }^{6}$ University of Medicine and Pharmacy Craiova, Romania \\ ${ }^{7}$ Department of General Surgery, "Bagdasar-Arseni” Emergency Hospital Bucharest, Romania
}

*corresponding author: dragos.serban@umfcd.ro

\begin{abstract}
The molecular mechanisms involved in the appearance of oedema and blisters induced by the mustard gas are not fully elucidated, which justifies the difficulty of identifying effective medical countermeasures for the treatment of skin lesions. The paper aims to compare the skin toxicity produced by the chemical compound mustard gas and its synthetic analogue 2clorethyl-ethyl sulphide (CEES), as well as the development and experimental testing of a transdermally absorbed therapeutic formula, whose components pharmacodynamically antagonize the toxicity of these compounds. The experimental results highlighted the following: the synthetic analogue 2-clorethyl-ethyl sulphide (CEES), due to its lower toxicity, is a valid alternative for the laboratory study of blistering chemicals; in vitro evaluation of cell viability in case of CEES exposure revealed cytotoxicity correlated with the dose partially antagonized by the administration of the complex antidote; contamination of the skin with doses of $4.5 \mu \mathrm{L} / \mathrm{cm}^{2}$ mustard gas and $10 \mu \mathrm{L} / \mathrm{cm}^{2}$ CEES, respectively, did not produce aggressions such as chain breaks in the DNA; the in vivo assessment of the toxicity of mustard and its synthetic analogue CEES revealed that the administration of the complex antidote showed 30\% protection for mustard gas and $100 \%$ for CEES in case of percutaneous administration of the average lethal dose (LD50). The histopathological examination showed that the therapeutic effect generated on chemically assaulted areas is predominant by limiting ulcers and inflammation.
\end{abstract}

\section{Rezumat}

Mecanismele moleculare implicate în apariția edemului și a veziculelor induse de compusul mustard gas nu sunt complet elucidate, ceea ce justifică dificultatea identificării unor contramăsuri medicale eficiente pentru tratamentul leziunilor cutanate. Lucrarea își propune evaluarea comparativă a toxicității cutanate produse de compusul chimic mustard gas și de analogul său sintetic 2 clor-etil-etil sulfură (CEES), precum și realizarea și testarea experimentală a unei formule terapeutice cu absorbție transdermică, ale cărei elemente componente să antagonizeze farmacodinamic toxicitatea acestor compuși. Rezultatele experimentale au evidențiat următoarele aspecte: analogul sintetic CEES, datorită toxicitătiii mai reduse, reprezintă o alternativă validă pentru studiul în laborator al agenților chimici vezicanți; evaluarea in vitro a viabilității celulare în cazul expunerii la CEES a evidențiat citotoxicitate corelată cu doza parțial antagonizată de administrarea antidotului complex; contaminarea tegumentelor cu doze de $4,5 \mu \mathrm{L} / \mathrm{cm}^{2}$ mustard gas și respectiv $10 \mu \mathrm{L} / \mathrm{cm}^{2} \mathrm{CEES} \mathrm{nu}$ a produs agresiuni de tipul rupturilor catenare la nivelul ADN; evaluarea in vivo a toxicității iperitei și a analogului său sintetic CEES a evidențiat că administrarea antidotului complex a determinat o protecție de 30\% pentru mustard gas şi $100 \%$ pentru CEES în cazul administrării percutane a dozei letale medii (DL50). Examenul histopatologic a evidențiat faptul că efectul terapeutic generat pe zonele agresate chimic este predominat de limitare a ulcerațiilor şi a inflamaţiei.

Keywords: mustard gas, 2-chlorethyl-ethyl sulphide (CEES), toxicity, antidote

\section{Introduction}

Vesicants are chemical compounds that produce serious toxic effects on the eyes, lungs and skin through direct contact or inhalation of vapours [18]. They represent a family of compounds based on sulphur, nitrogen and oxygen, with similar chemical and biological properties
[12]. Their toxicity is determined by the presence of the central sulphur atom and the terminal chlorine group [10, 32]. Nitrogen-containing blister agents are known for their use as chemotherapeutic drugs, and sulphur blister agents are best known for their applications in armed conflicts [18]. The prototype 
of the latter class is mustard gas, by its chemical name bis(2-chloroethyl) sulphide.

The molecular mechanisms involved in the occurrence of oedema and blisters induced by the mustard gas compound are not fully elucidated, which justifies the difficulty of identifying effective medical countermeasures for the treatment of skin lesions $[7,8,11$, $12,34]$. Also, there are no experimental studies to prove the existence of a specific treatment for skin lesions caused by mustard gas [18, 24-26]. This context justifies the synthesis and characterization of a synthetic analogue of mustard gas with similar but less toxic properties, namely 2-clorethyl-ethyl sulphide (CEES) $[1,2]$.

The paper proposes as specific objectives the comparative assessment of skin toxicity produced by the chemical compound mustard gas and its synthetic analogue, 2-clorethyl-ethyl sulphide (CEES), as well as the development and experimental testing of a transdermal absorbed therapeutic formulation, whose components are able to antagonize the toxicity of these blistered compounds.

\section{Materials and Methods}

\section{Materials and reagents}

Mustard gas - vesicant chemical compound, $83 \%$ purity, product in the custody of the Center for Scientific Research for Defence CBRN and Ecology Bucharest, Romania; 2-clorethyl-ethyl sulphide (CEES) 97\% purity, Sigma-Aldrich, Germany; 3-(4,5-dimethylthiazol-2-yl)-2,5-diphenyltetrazolium bromide (MTT) cell viability determination kit, Sigma-Aldrich, Germany; Phospho-Histone H2A.X Antibody (CR55T33), Alexa Fluor 488, Thermo-Fisher, USA.

The following medicines were used to obtain the composition of the complex antidote: infliximab (Inflectra $^{\circledR}$, Pfizer Europe, Belgium); dexamethasone (Dexametazona fosfat KRKA ${ }^{\circledR} 4 \mathrm{mg} / \mathrm{mL}$, Krka, Czech Republic); ketoprofen (Ketoprofen Rompharm ${ }^{\circledR} 50$ $\mathrm{mg} / \mathrm{mL}$, Rompharm, Romania); N-acetylcysteine (Fluimucil ${ }^{\circledR} 100 \mathrm{mg} / \mathrm{mL}$, Zambon, Italy).

The formula of the complex antidote is the following: ketoprofen $5 \%$, dexamethasone $0.4 \%, \mathrm{~N}$-acetylcysteine $30 \%$, Infliximab 1\%, PEG $40020 \mathrm{~mL}$ and water for injections ad $100 \mathrm{~mL}$.

In vitro cytotoxicity studies

For in vitro cytotoxicity studies of vesicular compounds, using a MTT kit, a stock solution of 2 chloro-ethylethyl sulphide (CEES) was prepared by dissolving $347 \mu \mathrm{L}$ CEES solution of $97 \%$ concentration in 9.53 $\mathrm{mL}$ dimethylsulfoxide (DMSO). From this stock solution, the working solution of concentration 6 $\mathrm{mM} / 300 \mu \mathrm{L}$ was prepared by dissolving $1 \mu \mathrm{L}$ stock solution in $9 \mathrm{~mL}$ DMSO.

Laboratory equipment

EnSight multimodal reader ${ }^{\mathrm{TM}}$ Multimode Microplate Reader (Perkin Elmer, USA), used for optical density reading in the MTT method for determining cell viability using MTT cell proliferation kit; confocal microscope, Zeiss LMS 980 (Zeiss, Germany), used to identify focilloci $\mathrm{H} 2 \mathrm{AX}$ (phosphorylated histone H2AX antibody) on tissue using the technique of fluorescence microscopy; Zeiss Axiolab 5 light microscope (Zeiss, Germany) for histopathological examination of skin samples using haematoxylin-eosin staining (HE); gas chromatograph coupled to mass spectrometer $\mathrm{GC} /$ MS/MS 18-01 (Thermo Electron Corporation, UK), Trace Gold capillary column $30 \mathrm{~m}$ x $0.25 \mathrm{~mm}$ x 0.25 $\mu \mathrm{m}$ (Thermo Scientific); EXIGO H 400 veterinary haematology analyser (Boule Diagnostics; Sweden). In vitro evaluation of the cytotoxicity CEES using the MTT cell viability assay

An experimental in vitro toxicity assessment model of CEES was performed by incubating a fibroblast culture, NIH/3T3 ATCC $^{\circledR}$ CRL-1658 ${ }^{\mathrm{TM}}$ (ATCC, USA) $\left(10^{6}\right.$ cells $\left./ \mathrm{mL}\right)$ with $100 \mu \mathrm{L}(2 \mathrm{mM}$ CEES) of S1 solution of 2-chloroethylethyl sulphide and cytotoxicity testing using the MTT kit. The therapeutic efficacy of the complex antidote according to the protocol presented below was also tested in vitro under the same conditions.

Thus, for the cytotoxicity test of CEES the fibroblast cell line cultured in $25 \mathrm{~cm}^{2}$ cell culture vessels using Dulbecco's Modified Eagle's Medium (DMEM) (ATCC, USA) supplemented with $10 \%$ foetal bovine serum (FBS) (Thermo-Fisher, USA) and $50 \mu \mathrm{g} / \mathrm{mL}$ gentamicin. Cells were trypsinized with $0.025 \%$ trypsinEDTA, (Sigma-Aldrich, Germany) were centrifuged and the pellet resuspended in $5 \mathrm{~mL}$ of complete DMEM medium. Initial cell counting was performed by staining with Tripan Blue (Sigma-Aldrich, Germany) 1:1 (50 $\mu \mathrm{L}$ cell suspension $+50 \mathrm{~mL}$ Tripan Blue).

The cell suspension had a concentration of $1.07 \mathrm{x}$ $10^{6}$ cells $/ \mathrm{mL}$. To perform the cytotoxicity test, the cell suspension was cultured in a 96-wells microplate, $200 \mu \mathrm{L} /$ well $\left(2.14 \times 10^{5}\right.$ cells/well $)$ and incubated in a $5 \% \mathrm{CO}_{2}$ atmosphere at $37^{\circ} \mathrm{C}$ for 24 hours with $100 \mu \mathrm{L}$ of CEES S1 solution, or with $100 \mu \mathrm{L} \mathrm{S1}$ solution and $100 \mu \mathrm{L}$ complex antidote, respectively. $30 \mu \mathrm{L} \mathrm{MTT} /$ well $(10 \%$ of the volume of medium) was added and incubated for 4 hours at $37^{\circ} \mathrm{C}$ in a $\mathrm{CO}_{2}$ atmosphere. After 4 hours, the microplate was removed from the incubator, the medium was removed and the MTT solvent was added $(200 \mu \mathrm{L} /$ well $)$. The optical density was read at a wavelength of $570 \mathrm{~nm}$, up to one hour after the addition of the solvent. The samples were performed in triplicate.

The following formula is used to evaluate the results:

$\%$ cellular viability $=(\mathrm{OD}$ positive control $-\mathrm{OD}$

blank)/(OD negative control - OD blank) x 100,

where: Positive control $1=$ cells + CEES + MTT + solvent MTT; Positive control 2 = cells + CEES + complex antidote + MTT + MTT solvent; Negative 
control $=$ cells + MTT + MTT solvent; blank = medium (DMEM complete) + MTT + MTT solvent; $\mathrm{OD}=$ optical density.

In vivo evaluation of the toxicity of the synthetic analogue CEES and the efficacy of the treatment The laboratory animals were young male BALB/c mice (approx. 4 months old), weighing $25-30 \mathrm{~g}$, country of origin Romania, kept in microclimates adequately in compliance with the legislation in force on animal welfare. The diet was balanced, consisting of standard granulated food. The temperature, humidity and ventilation of the environment were controlled by the specialized staff of the biobase who permanently monitored the animals. The project received the Animal Ethics Commission Approval within the MedicalMilitary Research Centre, Bucharest, Romania.

An experimental in vivo toxicity model of the mustard gas and the synthetic analogue CEES was performed under the administration of toxic substances and of the complex antidote by using 5 groups of 5 mice epilated at the dorsal region on an area of approx. $4 \mathrm{~cm}^{2}$, as follows: Group 1 (control), to which a volume of $0.5 \mathrm{~mL} / \mathrm{cm}^{2}$ complex antidote was applied to the epilated dorsal region. Group 2, to which $4.5 \mu \mathrm{L} / \mathrm{cm}^{2}$ mustard gas of $83 \%$ purity (1 LD50 percutaneous) were applied, corresponding to the consumption norm according to AEP $58\left(5 \mathrm{~g} / \mathrm{m}^{2}\right)$ at the level of the epilated dorsal region. Group 3, to which $4.5 \mu \mathrm{L} / \mathrm{cm}^{2}$ mustard gas was applied and immediately, a dose of $0.5 \mathrm{~mL} / \mathrm{cm}^{2}$ complex antidote at the level of the epilated dorsal region. Group 4, to which CEES was applied in a dose of $10 \mu \mathrm{L} / \mathrm{cm}^{2}$ (1 LD50 percutaneous) at the level of the epilated dorsal region. Group 5, to which CEES was applied at a dose of $10 \mu \mathrm{L} / \mathrm{cm}^{2}$ (1 LD50 percutaneous) and immediately a volume of $0.5 \mathrm{~mL} /$ $\mathrm{cm}^{2}$ complex antidote at the level of the epilated dorsal region.

This way of comparing the control group with the intoxicated and treated groups was chosen because the complex antidote used for treatment does not contain new/unknown active substances that require additional safety studies. The substances in the complex antidote are known from preclinical and clinical papers approved by the European Medicines Agency (EMA) and National Medicine and Medical Devices Agency of Romania, with safety studies for human use.

GC-MS tests to identify mustard gas at the skin level

Six animals labelled with the chemical mustard gas blistering agent according to the skin contamination norm corresponding to $1 \mathrm{LD} 50$, respectively, $4.5 \mu \mathrm{L} /$ $\mathrm{cm}^{2}$. The chemical agent was left in contact with the skin for 30 minutes, and for 3 of the subjects the complex antidote in a volume of $0.5 \mathrm{~mL} / \mathrm{cm}^{2}$ was applied immediately after contamination on the contaminated surface. Sampling was performed 30 minutes after the animal's exposure to the chemicals by wiping the skin with dry swabs. The swabs were extracted into methylene chloride, concentrated and analysed by gas chromatography coupled with mass spectrometry.

The operational parameters of the method are the following: carrier gas Helium 6.0 (ultrapure), flow rate $1 \mathrm{~mL} /$ minute $(36.2 \mathrm{~cm} / \mathrm{s})$, constant pressure; injection method: splitless, $15 \mathrm{~mL} / \mathrm{min}$; temperature program: $60^{\circ} \mathrm{C}(2 \mathrm{~min}), 10^{\circ} \mathrm{C} / \mathrm{min}, 300^{\circ} \mathrm{C}(10 \mathrm{~min})$; scanned mass range: $40-650 \mathrm{~m} / \mathrm{z}$; injection volume: $1 \mu \mathrm{L}$.

Histopathological examination

All animals in the 5 groups were examined. Surviving animals were euthanised $\left(\mathrm{CO}_{2}\right.$ inhalation) at 7 days and fragments of skin and liver were sampled for assessment by histopathological techniques of the severity of lesions caused by the mustard gas vesicant compound and CEES, respectively. Three 9-mmdiameter wounds were made on the back, at the previously epilated dorsal region. These were fullthickness wounds at the superficial level. The haematoxylin-eosin staining (HE) technique was used for paraffin sections.

Statistical analysis

Statistical analysis was performed using Microsoft Excel 2010 software (Microsoft Corp., USA) and GraphPad Prism v. 5.0. (GraphPad Software, USA). The Student's T test was used for statistical analysis of all the experimental results with quantitative values. Results are expressed as mean \pm standard deviation.

\section{Results and Discussion}

In vitro evaluation of the cytotoxicity of CEES using the MTT cell viability assay

The Student's T test statistical analysis of the experimental results shows that the average values of the optical density corresponding to the cell viability of the cell solution, medium and MTT differ statistically significantly from the mean of the values corresponding to the cells treated with CEES solution $2 \mathrm{mM} / 100 \mathrm{~mL}$ (Table I).

Table I

In vitro evaluation of cytotoxicity of $2 \mathrm{mM} / 100 \mathrm{~mL}$ CEES solution using MTT cell viability assay

\begin{tabular}{|l|l|c|c|}
\hline No. & \multicolumn{1}{|c|}{ Control } & Optical density & CEES concentration $(\mathrm{mM})$ \\
\hline 1 & Negative control $^{*}$ & $0.535 \pm 0.017$ & 0 \\
\hline 2 & Positive control 1** & $0.172 \pm 0.019$ & 2 \\
\hline 3 & Positive control $2 * * *$ & $0.385 \pm 0.013$ & 2 \\
\hline
\end{tabular}

$*$ cells, MTT solvent and MTT; **cells + CEES + MTT + solvent MTT; ***cells + CEES + complex antidote +MTT + MTT solvent

The statistical analysis of the experimental results showed that the average values of the optical densities of the positive control 1 intoxicated with $2 \mathrm{mM}$ CEES and untreated differ statistically significantly from the 
average values of the negative control considered control $(p=0.0002)$ as well as the average values of the optical densities of positive control 2 , intoxicated with $2 \mathrm{mM}$ CEES and treated with the complex antidote $(\mathrm{p}=0.009)$. The synthetic analogue CEES shows a direct cytotoxic effect highlighted by the MTT test; cytotoxicity partially improved by the administration of the complex antidote. The cell viability when administering CEES-S1 solution ( $2 \mathrm{mM})$ was $26.98 \%$ and of $69.81 \%$, when administering CEES S1 solution and complex antidote.

In vivo assessment of toxicity of mustard gas and its synthetic analogue CEES

The results of the in vivo studies are presented in Table II.

\begin{tabular}{|c|c|c|c|c|c|c|}
\hline Group & LD50 & $\begin{array}{c}\text { Mustard gas } \\
\left(\mu \mathrm{L} / \mathrm{cm}^{2}\right)\end{array}$ & $\begin{array}{c}\text { Synthetic analogue } \\
(\mathrm{CEES}) \\
\left(\mu \mathrm{L} / \mathrm{cm}^{2}\right)\end{array}$ & $\begin{array}{c}\text { Complex } \\
\text { antidote } \\
\left(\mathrm{mL} / \mathrm{cm}^{2}\right)\end{array}$ & $\begin{array}{c}\text { Percentage mortality } \\
\text { at 72 hours }\end{array}$ & $\begin{array}{c}\text { Percentage mortality } \\
\text { at 7 days }\end{array}$ \\
\hline 1 & & - & 0 & 0.5 & 0 & 0 \\
\hline 2 & 1 & 4.5 & 0 & 0 & $30 \%$ & $30 \%$ \\
\hline 3 & 1 & 4.5 & 0 & 0.5 & 0 & $30 \%$ \\
\hline 4 & 1 & 0 & 10 & 0 & 0 & 0 \\
\hline 5 & 1 & 0 & 10 & 0.5 & 0 & 0 \\
\hline
\end{tabular}

The comparative analysis of the 7-day percentage mortality under the percutaneous application of the average lethal dose shows that, without treatment, the vesicant mustard gas is approximately 2 times more toxic than its synthetic analogue CEES (60\% mortality compared to $30 \%$ in the case of CEES). The application of the treatment in the case of the chemical compound vesicant mustard gas prolongs the duration and increases the survival rate by protecting in proportion of $30 \%$. In the case of the synthetic analogue CEES, the application of the treatment protects $100 \%$.

Histopathological examination

All skin fragments from all the 5 study groups underwent histopathological examination. The results were correlated with the applied chemicals. Within each group similar types of lesions were observed, but with slight variation in the severity. The animal with most severe lesions was chosen for presentation. The experimental results highlighted the following aspects:

Group 1 - non-intoxicated, treated only with the complex antidote (fragment of skin taken from the dorsal region with a thickness of approximately 10 microns): at the level of the skin layers, the histopathological exam showed no solutions of continuity, inflammatory or haemorrhagic elements (Figures 1a and $1 \mathrm{~b}$ ), and the skin appendages are present and have a normal appearance.

Groups 2 and 4 intoxicated with 1 LD50 chemical compound vesicant mustard gas (group 2) and respectively synthetic analogue CEES (group 4) and untreated: the patterns of cellular aggression exerted at the skin level secondary to exposure to mustard are: interface dermatitis with vacuolar and lichenoid type, spongiform and bullous dermatitis (with or without acantholysis), alteration of the derm/hypoderm ratio by sclerodermiform changes. The predominant lesions in the cases of subjects exposed to chemical aggression were superimposable on chemical necrosis with biological features expressed by: the presence of a predominantly acute inflammatory infiltrate, consisting of PMNs and rare macrophages, extended from the hypodermic level, including peri-adnexal and in the band adjacent to the basal layer; vascular congestion in the deep layers, secondary to the irritative effect; basal layer cell hyperplasia, with mitotic figures and cytoplasmic vacuolization; thickening of the spinous layer, with the appearance of acanthosis and highlighting the intercellular junctions, alternating with areas of acantholysis; thickening of the granular and horny layer by increasing the necrotic elements and implicitly the acceleration of the cutaneous cellular turnover; bacterial colonized fibrinoid-hematic crust, oedematous underlying connective tissue (Figures $2 \mathrm{a}$ and $2 \mathrm{~b}$ ).

Groups 3 and 5 intoxicated with 1 LD50 mustard gas (group 3) and CEES (group 5) and treated with the complex antidote: histopathological examination shows skin fragments with lesions secondary to the stressor (mustard gas) with areas of skin dilaceration and continuity solutions covered by fibrino-hematic crust, bacterially colonized. Compared to untreated subjects, there is a limitation of inflammatory infiltrate and ulcers, with an impact on the granulation tissue that does not have neoformation vessels, inflammatory elements or fibroblasts. Adjacent to the chemically induced trauma, hyperplasia of the spy layer is observed due to the predominance of the dermal papillae and of the adjacent squamous layer, constituting areas of acanthosis. 
FARMACIA, 2021, Vol. 69, 2
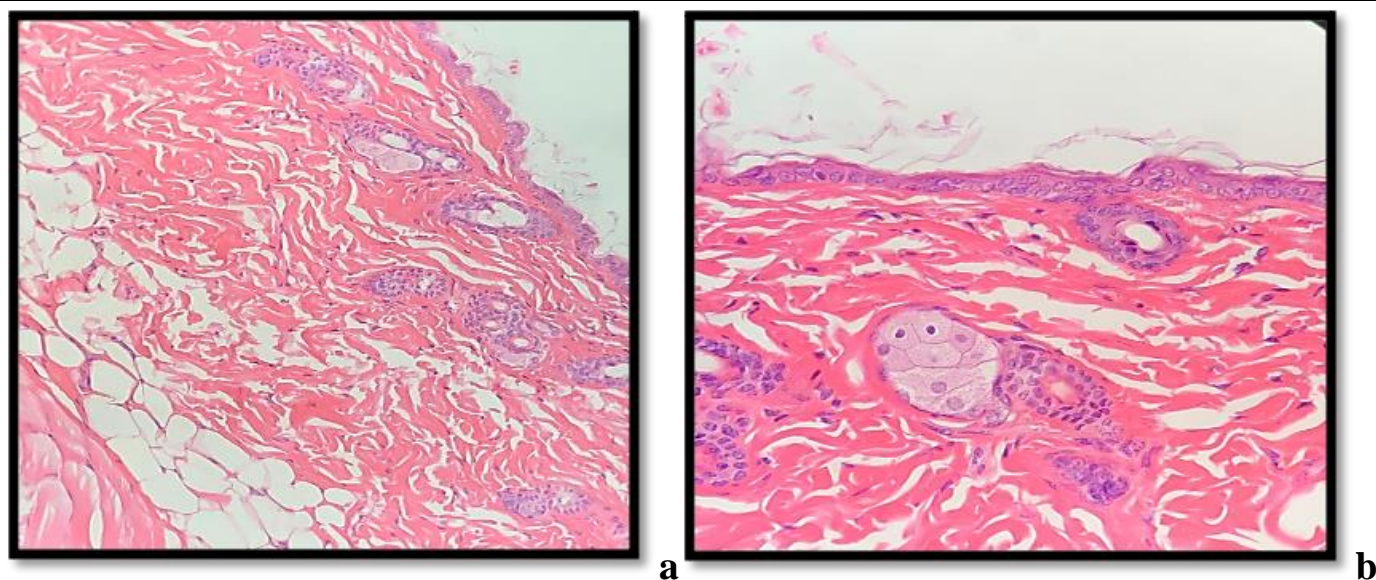

Figure 1.

a) colour HE, 20X. skin fragment, without continuity solutions or inflammatory or haemorrhagic infiltrate;

b) HE coloration, $40 \mathrm{X}$
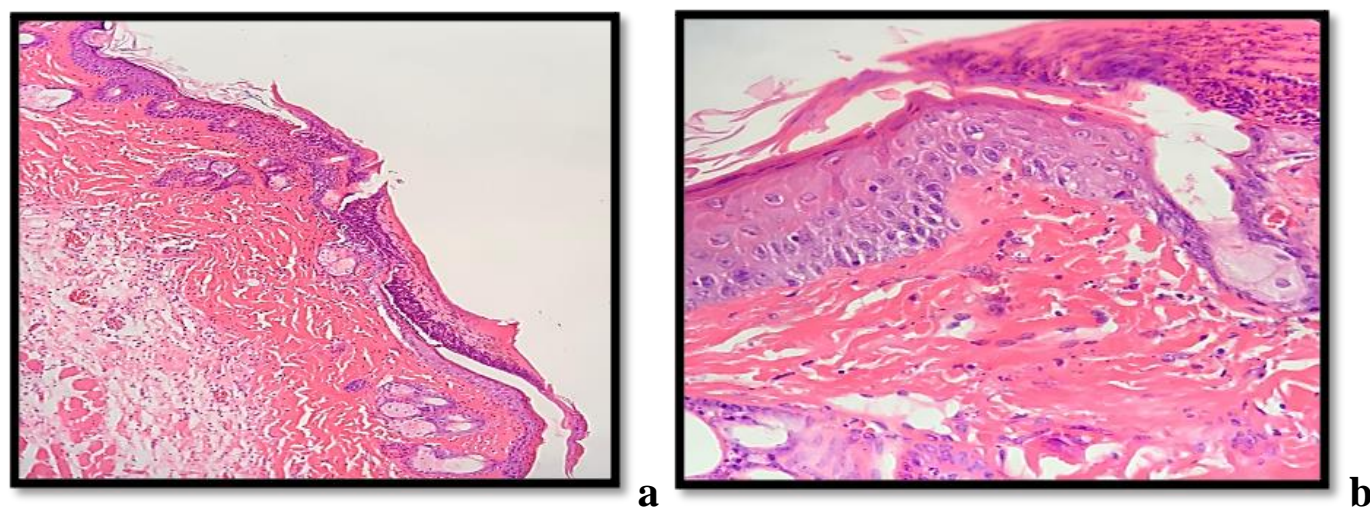

Figure 2.

a) histopathological lesions in lot 2 (gas mustard): HE, $20 \mathrm{X}$. Fibrin-hematic crust developed in the segment of continuity of the skin. Adjacent. The area of acanthosis (top right) and acantholysis (underlying the crust) with a bullous appearance. Inflammatory infiltrate existing up to the hypodermic level, where capillary congestion and rare blood extravasations are observed; b) histopathological lesions in lot 4 (CEES): HE, 40X. skin that shows the thickening of all layers, with the amplification of the basal layer, at the level of which cytoplasmic clarifications are partially identified, and linear and diffuse inflammatory infiltrate, similar to prickly dermatitis; of the spinous layer where areas of acanthosis and obvious desmosomal junctions are identified; the granular and horny layer are thickened due to the acceleration of cell turnover through necrosis generated by the chemical and bacteriological impact
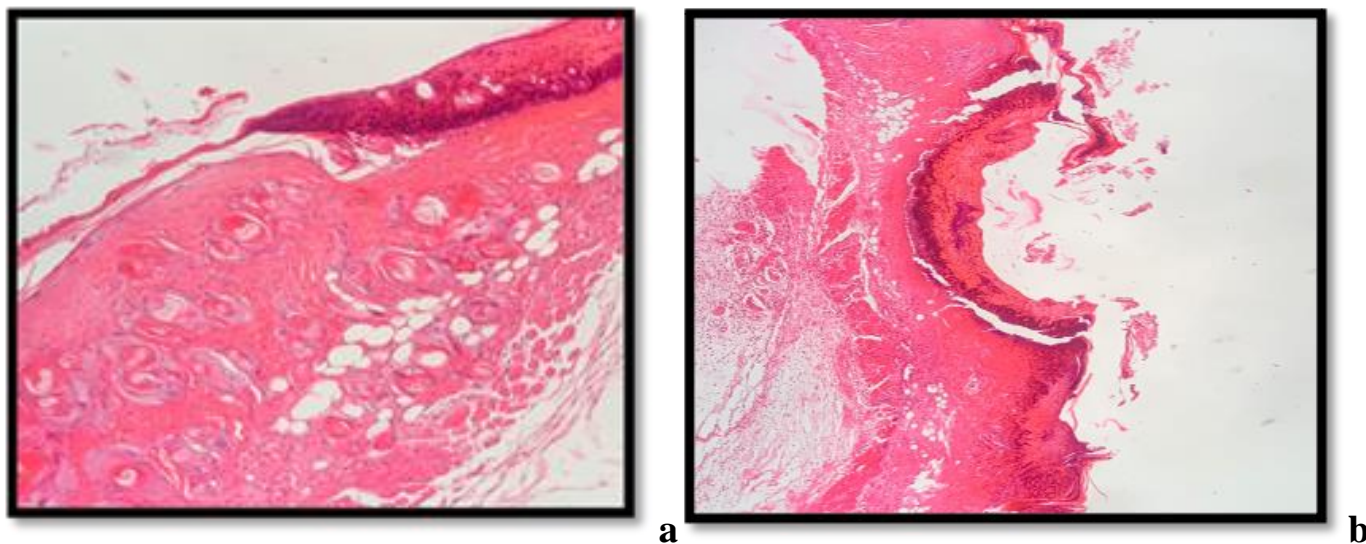

Figure 3.

a) HE, 20X Skin with fibrin-hematic crust; adjacent, acanthosis with hyperplasia of the dermal papillae; b) blisters in the area of skin ulceration, with minimal adjacent inflammatory infiltrate 
GC-MS analyses to identify residual amounts of mustard gas at skin level

Representative chromatograms of the samples from animals exposed to mustard gas (coded CBRN/L1/
$2020 / \mathrm{S} 1$, with a peak area of $353,371,135$ units) and animals exposed to mustard gas and antidote (coded CBRN/L1/2020/ST1, with a peak area of 171,237,277 units) are presented in Figure 4 and Figure 5, respectively.

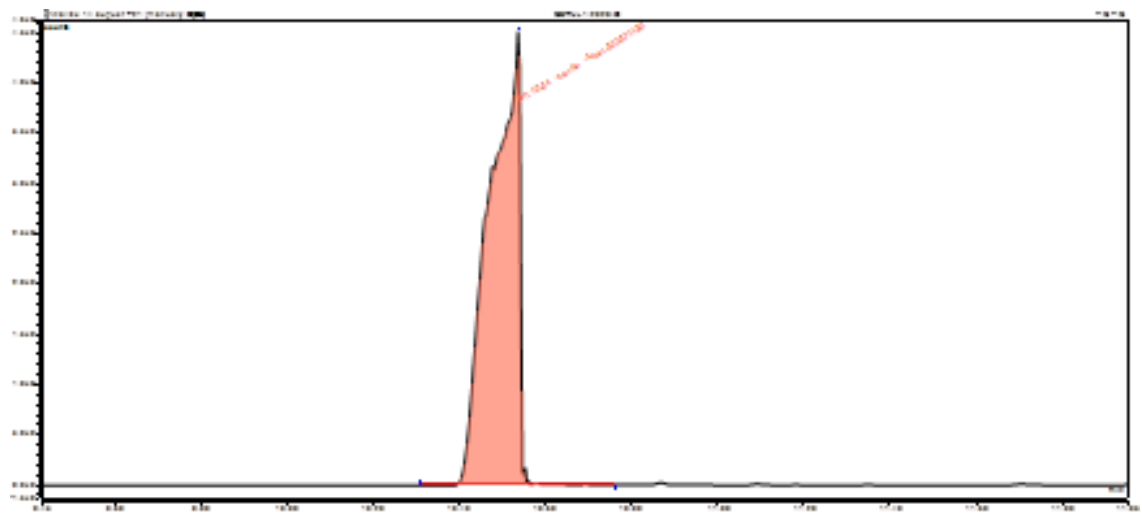

Figure 4.

Total ion chromatogram of CBRN/L1/2020/S1

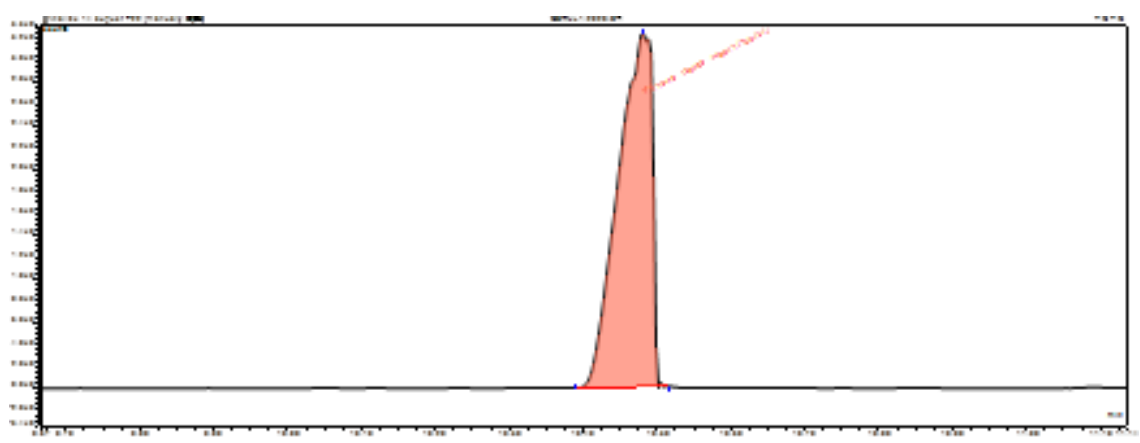

Figure 5.

Total ion chromatogram of sample CBRN/L1/2020/ST1

The analysis of the areas of the compound of interest in the two samples showed that after the application of the complex antidote the amount of toxic found in the ST1 sample is reduced to half of the amount with which the subjects were marked. The complex antidote could neutralize the residual toxic compound on the skin surface due to $\mathrm{N}$ acetylcysteine, an antioxidant compound that donates $\mathrm{SH}$ groups.

The chemical compound mustard gas is a highly toxic vesicant in case of skin exposure, the pathogenic mechanisms being multiple and still a subject of research. The molecular mechanisms involved in the pathogenesis of skin aggressions produced by the mustard gas compound and its synthetic analogue CEES are the consequence of their alkylating, prooxidizing and of inflammation mediators activating properties [3-5, 14, 33]: oxidative aggression by GSH depletion and increased nitric oxide synthesis [5]; nitric oxide (NOS) synthetases from mononuclear phagocytes and neutrophils are also important mediators involved in the pathogenesis of inflammation. The mechanism of up-regulation of iNOS expression leads to increased synthesis of nitric oxide (NO), a strong oxidizing agent. [27]; irreversible damage to the DNA strand: alkylation of guanine at position $\mathrm{N} 7$ and adenine at position N3 which have the effect of producing G-C to A-T transitions during replication, lethal at the cellular level [25]; activation of cyclooxygenase-derived prostaglandins (COX and COX-2) [9, 32]; activation of proinflammatory cytokines (IL6, TNF $\alpha$ ) [34]. The clinical manifestations related to mustard gas exposure occur with a latency of several tens of minutes or hours, depending on the dose and the mode of exposure [21]. The lethal oral dose for humans is $200 \mathrm{mg}$. The most common manifestations occur in the eyes, respiratory system and skin. Initially, the exposed subject perceives a faint smell of sulphur or garlic. At 30 - 60 minutes, nausea, vomiting and eye pain and tearing appear. The eyes are extremely sensitive to mustard gas toxicity, even low doses may provide incapacitation and visual impairment. In cases of exposure to less than $50 \mathrm{mg} / \mathrm{min} / \mathrm{m}^{3}$, mild conjunctivitis and corneal swelling. After several hours of exposure, at a concentration of $200 \mathrm{mg} / \mathrm{min} / \mathrm{m}^{3}$ or more, the corneal oedema becomes severe, significantly decreased vision or even temporary blindness. Increased concentration of mustard gas leads to damage of limbal 
stem cells, which can be permanent, with chronic corneal oedema and neovascularization [13, 16, 29]. After 2 - 6 hours respiratory symptoms develop, with cough, sneezing, sore throat and difficulty in breathing. The cough becomes productive after 24 - 48 hours, signalling the beginning of epithelial healing.

The skin lesions appear 2 - 24 hours postexposure, being characterized by itching, pain and burning sensation, with local hyperaemia in the first hours, followed by serous-haemorrhagic blisters usually after 24 hours [17, 27, 29]. Blisters developed from small vesicles that become coalescent, forming large sheets of epithelium, with secondary hydro-electrolytic impairment [20, 27]. In the following 2 - 6 days, there is a significant risk of wound infection. If correct managed, the healing process starts after 10 - 50 days, with pigmentary changes that may remain for months or years $[29,30]$.

As general management, all victims should be removed from the exposure area as soon as possible, clothes removed and the exposed skin should be washed abundantly with water and soap with neutral $\mathrm{pH}$. If eyes are exposed, lavage with large quantities of Ringer or saline solution are necessary to remove the toxic. Up to date, there is no local or systemic antidotes for mustard gas exposure. Experimental studies showed that parenteral administration of a combination of sodium thiosulfate $(3000 \mathrm{mg} / \mathrm{kg})$, vitamin E $(20 \mathrm{mg} /$ $\mathrm{kg})$, or dexamethasone $(8 \mathrm{mg} / \mathrm{kg})$ within 15 minutes of exposure may reduce the associated tissue and organ damages. The pharmacological effect combines the scavenger role of thiosulfate for alkylant agents such as mustard gas, with antioxidants effects of vitamin $\mathrm{E}$ and anti-inflammatory action of corticosteroids. However, the use was not employed in human treatment of mustard gas intoxications. $\mathrm{N}$-acetylcysteine administered orally a maximum dose of $600 \mathrm{mg} /$ daily, or $1200 \mathrm{mg} /$ daily, $1800 \mathrm{mg} /$ daily, showed in clinical trials clinical improvements of lung function, though longer evidence is needed to be prescribed in current practice [1, 27, 28, 31].

Local management of skin wounds involves, in the first stage limiting inflammation by corticosteroids ointments, preventing bacterial superinfection using a topical bacteriostatic agent, such as silver sulphadiazine $1 \%$ and pain and itching control with general or local medication. Pain may be controlled with mild analgesic and antihistaminic [9] drugs in mild to moderate intoxications, but requires narcotics (morphine sulphate) in severe cases. Topical combinations based on phenol $1 \%$ and menthol $1 \%$ or capsaicin $(0.025 \%)$ showed partial relief of pain and pruritus in exposed patients [30]. Surgical or laser dermal debridement of the vesicles and necrotic lesions is considered useful to speed recovery. In severe and extensive burn, skin graft may be required, after debridement [22, 27, 29]. An antidote formula for topical use has been developed in the present study, which has been shown to be effective in limiting the skin toxicity of mustard gas. Due to the increased toxicity of mustard gas, its synthetic analogue CEES, has been a valid experimental alternative for scientific research studies on the pathogenic mechanisms involved and the identification of effective therapeutic solutions. [2, 14, 26]. In vitro evaluation of cell viability in case of CEES exposure revealed cytotoxicity correlated with the dose partially antagonized by the administration of the complex antidote.

The complex antidote was formulated so that through its components it would pharmacodynamically antagonize the toxic effects of the chemical compound mustard gas and its synthetic analogue. The amount of residual toxic vesicant compound identified by the GC-MS technique after application of the toxicant to laboratory animals was halved immediately after treatment. In vivo evaluation demonstrated that the administration of the complex antidote showed $30 \%$ protection for mustard gas and $100 \%$ for CEES in the case of percutaneous administration of the average lethal dose (1 LD50). Histopathological examination showed that the therapeutic effect generated on chemically assaulted areas is predominant by limiting ulcers and inflammation. Further studies, on human subjects are needed to establish the adequate therapeutic doses and the possibility of a personalized treatment for greater efficacy [23].

\section{Conclusions}

The experiment demonstrates the type of lesions induced by exposure to mustard (ulceration with abundant diffuse inflammatory infiltrate, arranged to the deep layers), the lesion pattern being predominantly lichenoid and bullous. The therapeutic effect generated on chemically aggressed areas is predominant characterized by limiting ulcers and inflammation, but without succeeding in total remission of the necrosis foci formed, due to the high degree of toxicity of blister agents. The results are encouraging, but further studies, on large number of subjects are necessary before testing the efficiency of the developed antidote on human patients.

\section{Conflict of interest}

The authors declare no conflict of interest.

\section{References}

1. Achanta S, Chintagari NR, Brackmann M, Balakrishna S, Jordt SE, TRPA1 and CGRP antagonists counteract vesicant-induced skin injury and inflammation. Toxicol Lett., 2018; 293: 140-148.

2. Aricò F, TundoP, Mustard analogues. Pure Appl Chem., 2016; 88(1-2): 3-16.

3. Behm B, Babilas P, Landthaler M, Schreml S, Cytokines, chemokines and growth factors in wound healing. J Eur Acad Dermatol Venereol., 2012; 26(7): 812-820.

4. Bielefeld KA, Amini-Nik S, Alman BA, Cutaneous wound healing: recruiting developmental pathways 
FARMACIA, 2021, Vol. 69, 2

for regeneration. Cell Mol Life Sci., 2013; 70(12): 2059-2081.

5. Black AT, Joseph LB, Casillas RP, Heck DE, Gerecke DR, Sinko PJ, Laskin DL, Laskin JD, Role of MAP kinases in regulating expression of antioxidants and inflammatory mediators in mouse keratinocytes following exposure to the half mustard, 2chloroethyl ethyl sulfide. Toxicol Appl Pharmacol., 2010; 245: 352-360.

6. Chang YC, Wang JD, Svoboda KK, Casillas RP, Laskin JD, Gordon MK, Gerecke DR, Sulfur mustard induces an endoplasmic reticulum stress response in the mouse ear vesicant model. Toxicol Appl Pharmacol., 2013; 268(2): 178-187.

7. Chang YC, Wang JD, Hahn RA, Gordon MK, Joseph LB, Heck DE, Heindel ND, Young SC, Sinko PJ, Casillas RP, Laskin JD, Laskin DL, Gerecke DR, Therapeutic potential of a non-steroidal bifunctional anti-inflammatory and anti-cholinergic agent against skin injury induced by sulfur mustard. Toxicol Appl Pharmacol., 2014; 280(2): 236-244.

8. Casillas RP, Kiser RC, Truxall JA, Singer AW, Shumaker SM, Niemuth NA, Ricketts KM, Mitcheltree LW, Castrejon LR, Blank JA, Therapeutic approaches to dermatotoxicity by sulfur mustard. I. Modulaton of sulfur mustard-induced cutaneous injury in the mouse ear vesicant model. J Appl Toxicol., 2000; 20(Suppl 1): S145-S151.

9. De Filippo K, Dudeck A, Hasenberg M, Nye E, van Rooijen N, Hartmann K, Gunzer M, Roers A, Hogg N, Mast cell and macrophage chemokines CXCL1/CXCL2 control the early stage of neutrophil recruitment during tissue inflammation. Blood, 2013; 121(24): 4930-4937.

10. Graham JS, Chilcott RP, Rice P, Milner SM, Hurst CG, Maliner BI, Wound healing of cutaneous sulfur mustard injuries: strategies for the development of improved therapies. J Burns Wounds., 2005; 4: e1: $1-45$.

11. Graham JS, Schoneboom BA, Historical perspective on effects and treatment of sulfur mustard injuries. Chem Biol Interact., 2013; 206(3): 512-522.

12. Ghabili K, Agutter PS, Ghanei M, Ansarin K, Panahi Y, Shoja MM, Sulfur mustard toxicity: history, chemistry, pharmacokinetics, and pharmacodynamics. Critical Rev Toxicol., 2011; 41: 384-403.

13. Goverman J, Montecino R, Ibrahim A, Sarhane KA, Tompkins RG, Fagan SP, Sulfur mustard gas exposure: case report and review of the literature. Ann Burns Fire Disasters, 2014; 27(3): 146-150.

14. Inturi S, Tewari-Singh N, Gu M, Shrotriya S, Gomez J, Agarwal C, White CW, Agarwal R, Mechanisms of sulfur mustard analog 2-chloroethyl ethyl sulfideinduced DNA damage in skin epidermal cells and fibroblasts. Free Radic Biol Med., 2011; 51: 22722280.

15. Jain $\mathrm{AK}$, Tewari-Singh $\mathrm{N}, \mathrm{Gu} \mathrm{M}$, Inturi $\mathrm{S}$, White $\mathrm{CW}$, Agarwal R, Sulfur mustard analog, 2-chloroethyl ethyl sulfide-induced skin injury involves DNA damage and induction of inflammatory mediators, in part via oxidative stress, in SKH-1 hairless mouse skin. Toxicol Lett., 2011; 205(3): 293-301.

16. Javadi MA, Yazdani S, Sajjadi H, Jadidi K, Karimian F, Einollahi B, Ja'farinasab MR, Zare M, Chronic and delayed-onset mustard gas keratitis: report of 48 patients and review of literature. Ophthalmology, 2005; 112(4): 617-625.

17. Joseph LB, Gerecke DR, Heck DE, Black AT, Sinko PJ, Cervelli JA, Casillas RP, Babin MC, Laskin DL, Laskin JD. Structural changes in the skin of hairless mice following exposure to sulfur mustard correlate with inflammation and DNA damage. Exp Mol Pathol., 2011; 91(2): 515-527.

18. Kehe K, Szinicz L, Medical aspects of sulphur mustard poisoning. Toxicology, 2005; 214: 198-209.

19. Keyser BM, Andres DK, Holmes WW, Paradiso D, Appell A, Letukas VA, Benton B, Clark OE, Gao X, Ray P, Anderson DR, Ray R, Mustard Gas Inhalation Injury: Therapeutic Strategy. Int J Toxicol., 2014; 33(4): 271-281.

20. Maranda EL, Ayache A, Taneja R, Cortizo J, Nouri K, Chemical Warfare's Most Notorious Agent Against the Skin: Mustard Gas-Then and Now. JAMA Dermatol., 2016; 152(8): 933.

21. Manandhar E, Pay A, Veress LA, Logue BA, Rapid analysis of sulfur mustard oxide in plasma using gas chromatography-chemical ionization-mass spectrometry for diagnosis of sulfur mustard exposure. J Chromatogr A, 2018; 1572: 106-111.

22. Marinescu SA, Bejinariu GC, Boiangiu AM, Georgescu Balaceanu A, Gherghiceanu F, Giuglea C, Study on the concentrate of proteolytic enzymes enriched in bromelain and its effects on intermediate and extensive burns. Farmacia, 2019; 67(3): 522-550.

23. Neamtu M, Rusu RN, Ababeu DC, Bild W, Gavrilovici C, Stana B, Bild V, Review molecular backgrounds of individualised pharmacotherapy. Farmacia, 2020; 68(3): 396-405.

24. Oprescu DN, Bacalbasa N, Balescu I, Filipescu A, Urinary Tract Resections in Advanced-stage Cervical Cancer - A Series of Eight Cases. Anticancer Res., 2017; 37(6): 3271-3276.

25. Paromov V, Suntres Z, Smith M, Stone WL, Sulfur mustard toxicity following dermal exposure: role of oxidative stress, and antioxidant therapy. J Burns Wounds, 2007; 7: e7: 1-26.

26. Paromov V, Kumari S, Brannon M, Kanaparthy NS, Yang H, Smith MG, Stone WL, Protective effect of liposome-encapsulated glutathione in a human epidermal model exposed to a mustard gas analog. $J$ Toxicol., 2011; 2011:109516: 1-11.

27. Rafati-Rahimzadeh M, Rafati-Rahimzadeh M, Kazemi S, Moghadamnia AA, Therapeutic options to treat mustard gas poisoning - Review. Caspian J Intern Med., 2019; 10(3): 241-264.

28. Razavi SM, Saghafinia M, Davoudi SM, Salamati $\mathrm{P}$, Effects of sulfur mustard on the skin and their management: reviewing the studies conducted on Iranian chemical victims. Iran J Dermatol., 2013; 16(1): 21-30

29. Savu C, Melinte A, Posea R, Galie N, Balescu I, Diaconu C, Cretoiu D, Dima S, Filipescu A, Balalau C, Bacalbasa N, Pleural Solitary Fibrous Tumors-A Retrospective Study on 45 Patients. Medicina (Kaunas), 2020; 56(4): 185: 1-13.

30. Shakarjian MP, Heck DE, Gray JP, Sinko PJ, Gordon MK, Casillas RP, Heindel ND, Gerecke DR, Laskin DL, Laskin JD, Mechanisms mediating the vesicant 
actions of sulfur mustard after cutaneous exposure. Toxicol Sci., 2010; 114(1): 5-19.

31. Steinritz D, Striepling E, Rudolf KD, Schröder-Kraft C, Püschel K, Hullard-Pulstinger A, Koller M, Gandor F, Gawlik M, Medical documentation, bioanalytical evidence of an accidental human exposure to sulfur mustard and general therapy recommendations. Toxicol Lett., 2016; 244: 112-120.

32. Su Y, Richmond A, Chemokine Regulation of Neutrophil Infiltration of Skin Wounds. Adv Wound Care (New Rochelle), 2015; 4(11): 631-640.
33. Tewari-Singh N, Rana S, Gu M, Pal A, Orlicky DJ, White CW, Agarwal R, Inflammatory biomarkers of sulfur mustard analog 2-chloroethyl ethyl sulfideinduced skin injury in SKH-1 hairless mice. Toxicol Sci., 2009;108(1): 194-206.

34. Wormser U, Brodsky B, Proscura E, Foley JF, Jones $\mathrm{T}$, Nyska A, Involvement of tumor necrosis factoralpha in sulfur mustard-induced skin lesion; effect of topical iodine. Arch Toxicol., 2005; 79(11): 660-670. 